\title{
RANCANG BANGUN SISTEM INFORMASI PENGAJUAN KREDIT PADA BUM DESA BERSAMA SANTHI SEDANA
}

\author{
Putu Risma Emiliana Pande (1), I Nyoman Tri Anindia Putra ${ }^{(2)}$, Ni Wayan Suardiati Putri (3) \\ Teknik Informatika \\ STMIK STIKOM Indonesia \\ e-mail : rismaemilia69@gmail.com ${ }^{(1)}$, trianindiaputra@gmail.com ${ }^{(2)}$
}

\begin{abstract}
BUM Desa Bersama Santhi Sedana is a village-owned enterprise in which the financial comes from the village wholly or partially. The funds that have been collected or saved by the villageowned enterprise Santhi Sedana are channeled to the community or the country folk in the form of credits that can give the villagers lot of advantages as well as the prosperity of the villagers. For the people who put a willingness to apply for credit are required to come directly to the office of BUM Desa Bersama Santhi Sedana, sometimes some of the people have to come to the office repeatedly, perhaps they accidentally perform any certain mistake or just to complete the credit application file. The purpose of this research is to build an information system that can facilitate the customers in applying for credit and assist employees in managing customer credit data. This credit information system was built by data collection methods namely observation, interview, documentation, and library studies. System testing was done by black-box testing from the test results, the system is expected to be able to manage customer credit application and customer credit payment data later on.
\end{abstract}

Keywords : System, Credit, BUM Desa

BUM Desa Bersama Santhi Sedana merupakan badan usaha milik desa yang sebagian atau seluruh modalnya berasal dari desa. Dana yang dihimpun tersebut disalurkan lagi kepada masyarakat dalam bentuk kredit yang dapat memberikan keuntungan financial serta kesejahteraan masyarakat desa. Untuk masyarakat yang ingin mengajukan kredit harus datang ke kantor BUM Desa Santhi Sedana, tidak jarang masyarakat harus mendatangi kantor berulangkali untuk melengkapi berkas pengajuan kredit. Tujuan dilakukan penelitian ini adalah untuk membangun sistem informasi yang dapat memudahkan nasabah dalam mengajukan kredit dan membantu pegawai dalam mengelola data kredit nasabah. Sistem informasi kredit ini, dibangun dengan metode pengumpulan data yakni observasi, wawancara, dokumentasi, dan studi pustaka. Pengujian sistem dilakukan dengan black box testing dimana dari hasil pengujian, sistem yang dibangun mampu mengelola pengajuan kredit nasabah dan data pembayaran kredit nasabah.

Kata Kunci : Sistem, Kredit, BUM Desa

\section{PENDAHULUAN}

BUM Desa (Badan Usaha Milik Desa) merupakan badan usaha yang seluruh atau sebagian besar modalnya dimiliki oleh desa, melalui penyertaan modal langsung yang berasal dari kekayaan desa, yang dipisahkan guna mengelola aset, jasa pelayanan, dan usaha lainnya untuk sebesar-besarnya kesejahteraan masyarakat desa, sebagaimana telah disinggung dalam Undang-Undang No.6 Tahun 2014 tentang Desa.

BUM Desa Bersama Santhi Sedana Kecamatan Bangli merupakan Badan Usaha Milik Desa tingkat kecamatan, yang dihimpun oleh 9 desa dan kelurahan di Kecamatan Bangli. BUM Desa ini memiliki dua unit bisnis, salah satunya Unit Bisnis Keuangan yang memberikan pinjaman dana/kredit kepada masyarakat. Pembiayaan atau kredit adalah penyediaan uang atau tagihan yang dapat dipersamakan dengan itu, berdasarkan persetujuan atau kesepakatan antara bank dengan pihak lain yang mewajibkan pihak yang dibiayai untuk mengembalikan uang atau tagihan tersebut setelah jangka waktu tertentu dengan imbalan atau bagi hasil (Kasmir, 2016). Masyarakat yang ingin meminjam dana harus melengkapi syarat kredit seperti jaminan berupa BPKB/SK, proposal pengajuan, fotokopi KK, fotokopi KTP penanggung dan tertanggung. Untuk jaminan kredit dokumen asli wajib diserahkan yang nantinya akan disimpan oleh BUM Desa. 
BUM Desa memiliki 50 nasabah kelompok, yang setiap kelompok terdiri dari 10 orang dan 150 nasabah perorangan. Pengajuan kredit dapat diajukan secara perseorangan maupun kelompok. Setiap masyarakat yang akan mengajukan kredit harus datang ke kantor BUM Desa untuk melengkapi formulir pengajuan kredit yang disediakan BUM Desa, untuk calon nasabah kelompok setiap pengajuan kredit harus menyertakan berkas proposal pengajuan. Namun tidak jarang petugas langsung yang mengisi formulir melalui data yang diserahkan oleh pemohon. Selanjutnya formulir pengajuan tersebut dicatat dalam buku daftar tunggu pengajuan. Setiap pengajuan yang masuk akan dilakukan verifikasi oleh Tim Verifikasi, untuk mengecek keabsahan data pengajuan, dengan melakukan verifikasi langsung. Apabila berkas pengajuan yang dilampirkan seperti fotokopi KTP peminjam, fotokopi KTP penanggung, fotokopi KK, fotokopi slip gaji, dan jaminan, serta proposal pengajuan yang disertakan benar dan memenuhi syarat, selanjutnya dilakukan rapat hasil verifikasi, bersama Tim Pemutus Pinjaman (TPP). TPP ini terdiri dari Ketua Badan Kerjasama Antar Desa, Ketua BUM Desa Bersama Santhi Sedana, dan Ketua Unit Bisnis Keuangan. Jika TPP menyetujui hasil verifikasi maka pemohon dinyatakan layak didanai. Proses pencairan dapat dilakukan sesuai permohonan pemohon. Untuk nasabah kelompok pencairan dilakukan dengan didampingi kepala desa setempat. Jika pencairan sudah dilaksanakan maka berkas kelengkapan pengajuan, data verifikasi, dan berita acara dijadikan dalam satu buku dijilid rapi tanpa berkas salinannya. Untuk pembayaran setiap nasabah diberikan bukti berupa nota, kemudian dicacatan dalam kartu pembayaran nasabah. Setiap nasabah wajib melakukan pembayaran angsuran rutin setiap bulan.

Sistem informasi adalah kumpulan antara sub-sub sistem yang saling berhubungan yang membentuk suatu komponen yang didalamnya mencangkup input-proses-output yang berhubungan dengan pengolahan data menjadi informasi sehingga lebih berguna bagi pengguna(Putra, Bisenna, \& Kartini, 2018). Penggunaan sistem informasi pengajuan kredit dapat memberikan kemudahan dalam proses pengajuan kredit. Informasi yang akurat serta tepat waktu dalam menyajikan data yang lengkap sangat dibutuhkan oleh instansi, organisasi dan perusahaan (Ira Zulfa, Putra, 2018). Dengan sistem ini, calon nasabah tidak harus datang ke kantor untuk melakukan proses pengajuan kredit. Setiap data pengajuan akan disimpan dalam sistem kemudian ditintaklanjuti oleh petugas dengan verifikasi langsung. Dalam hal pembayaran kredit, bukti pembayaran dapat dicetak melalui sistem sehingga dapat memudahkan pegawai dalam pencatatan pembayaran kredit.

Berdasarkan permasalahan di atas maka, dibuatlah sistem informasi dengan judul "Rancang Bangun Sistem Informasi Pengajuan Kredit Berbasis Web pada BUM Desa Bersama Santhi Sedana". Dengan adanya sistem informasi dapat membantu pegawai dan masyarakat dalam proses pengajuan kredit, berfungsi sebagai sarana pengajuan kredit, penyimpanan data nasabah, menyimpan transaksi pembayaran angsuran, dan memudahkan dalam pencarian informasi nasabah.

\section{METODE}

Sebuah pencapaian target memerlukan metode yang berkaitan dengan tujuan, luaran dan dampak (Putra, Kartini, \& Dewi, 2019). Pengumpulan data merupakan hal yang penting dilakukan sebelum melakukan penelitian. Dengan adanya pengumpulan data dapat memperoleh informasi yang dibutuhkan serta mempermudah dalam pengerjaan laporan penelitian ini (Ni Luh Putu Putri Vera Handayani, 2019). Pengumpulan data dibagi menjadi dua metode yaitu pengumpulan data primer dan sekunder. Adapun metode pengumpulan data yang digunakan dalam penelitian ini yaitu:

1. Data primer merupakan data yang didapat dari sumber pertama baik dari individu atau perseorangan seperti hasil dari wawancara atau hasil pengisian kuesioner yang biasa dilakukan oleh peneliti (Umar, 2013).Data primer diperoleh dengan wawancara kepada Ketua BUM Desa Bersama Santhi Sedana dari hasil wawancara penulis memperoleh informasi yang dapat dijadikan sebagai bahan penelitian, seperti proses pengajuan pinjaman yang dilakukan dengan mencatat dalam form pengajuan, kemudian dimasukkan lagi ke dalam buku daftar tunggu pinjaman. Observasi dilakukan untuk mengumpulkan data dengan cara pengamatan secara langsung terhadap alur proses pengajuan kredit.

2. Data sekunder adalah sumber data yang tidak langsung memberikan data kepada pengumpul data, misalnya lewat orang lain atau lewat dokumen (Sugiyono, 2015). Data 
sekunder diperoleh melalui dokumentasi, arsip-arsip, dan sumber data yang berhungan dengan penelitian.

Analisa Kebutuhan fungsional yang dibutuhkan dalam perancangan sistem ini yaitu:

1. Adanya keamanan hak akses yang berfungsi melindungi sistem seperti proses login, dalam proses ini tidak semua pihak mendapat hak akses dengan sembarangan.

2. Mengelola data pengguna, diperlukan pengelolaan data pengguna untuk memanajemen data penggguna yang berhubungan langsung dengan sistem.

3. Sistem harus mampu mengelola data nasabah, seperti menambah, mengubah, dan mencari data nasabah.

4. Sistem harus mampu mengelola data pengajuan kredit, seperti menampilkan form pengajuan kredit, menambah, mengubah dan mencari data pengajuan.

5. Sistem harus mampu mengelola data transaksi pembayaran kredit nasabah dan mencetak bukti pembayaran.

6. Sistem dapat menerima validasi pengajuan kredit.

7. Sitem harus dapat menampilkan laporan pembayaran kredit, laporan perkembangan kredit, dan laporan tunggakan kredit.

Dari analisa kebutuhan sistem, perancangan sistem dapat dirancangan melalui data flow diagram (Putra et al., 2018). Data Flow Diagram atau dalam bahasa Indonesia menjadi Diagram Alir Data (DAD) adalah refresentasi grafik yang menggambarkan aliran informasi dan transformasi informasi yang diaplikasikan sebagai data yang mengatur dari masukan (input) dan keluaran (output) (Sukamto \& Shalahudin, 2014). Data flow diagram merupakan gambaran alur dari sistem yang akan dibangun (Tri, Putra, \& Kartini, 2019). Gambaran dari aliran data/informasi yang berjalan dalam sistem, baik input maupun output dari sistem.Dalam sistem yang akan dibangun terdapat sembilan proses yang berjalan,yaitu

1. Proses mengelola data registrasi nasabah, dimana setiap nasabah yang akan mengajukan kredit harus melakukan registrasi data registrasi akan disimpan pada database data pengguna.

2. Prose mengelola login, setiap user dalam sistem harus melakukan login dengan menginput username dan password.

3. Proses mengelola data pengguna, entitas yang berberan dalam mengelola data ini yakni sekretaris. Sekretaris dapat menambah, mengubah, dan menghapus data dari pengguna, yang termasuk dalam pengguna di proses ini yakni pengurus BUM Desa.

4. Proses mengelola data nasabah, yang memiliki hak akses dari proses ini adalah sekretaris BUM Desa, di mana sekretaris dapat menambah, mengubah, dan menghapus data nasabah. Serta nasabah yang dapat hanya dapat melihat dan mengubah data dirinya.

5. Proses mengelola transaksi pengajuan kredit, pada proses ini nasabah dapat melakukan pengajuan kredit dan mengubah data pengajuan kredit yang diajukan.

6. Proses mengelola data verifikasi kredit, setiap pengajuan kredit akan dilakukan verifikasi atau pengecekan atas data pengajuan kredit yang diajukan nasabah. Di mana yang berperan dalam proses ini yakni Tim Verifikasi Kredit dari BUM Desa Bersama Santhi Sedana.

7. Proses validasi pengajuan kredit, dalam hal pengajuan kredit yang telah diverifikasi datanya akan dicek kembali oleh Tim Pemutus Pinjaman, disini pengambilan keputusan atas kelayakan pengajuan kredit diambil berdasakan hasil rapat dari Tim Pemutus Pinjaman, yang kemudian di-input dalam sistem sebagai persetuajuan maupun penolakan atas hasil verfikasi kredit nasabah.

8. Proses pembayaran kredit, setiap nasabah yang kreditnya telah disetujui wajib melakukan pembayaran setiap bulannya. Proses pembayaran akan di-input oleh Bendahara BUMDesa Bersama Santhi Sedana yang memiliki output berupa bukti pembayaran kredit.

9. Laporan , laporan disini terdiri dari tiga laporan yaitu laporan pembayaran kredit, laporan tunggakan kredit, dan laporan perkembangan kredit. 
Perancangan basis data dalam sistem ini bertujuan untuk memudahkan mengakses dan mengelola data. Secara lebih lengkap pemanfaatan basis data dilakukan untuk memenuhi tujuan kecepatan, kemudahan, efisiensi ruang penyimpanan, keakuratan, ketersediaan, kelengkapan, keamanan dan pemakaian bersama (Hidayatullah \& Kawistara, 2017). Basis data disini merupakan kumpulan data yang dibutuhkan sistem yang saling berhubungan. Adapun terdapat 8 tabel yang digunakan dalam perancangan basis data dalam sistem ini yaitu
1. Tabel Kredit
2. Tabel Kredit Kelompok
3. Tabel Detail Kredit Kelompok
4. Tabel Kredit Perorangan
5. Tabel Nasabah
6. Tabel Pengguna
7. Tabel Validasi Kredit
8. Tabel Pembayaran

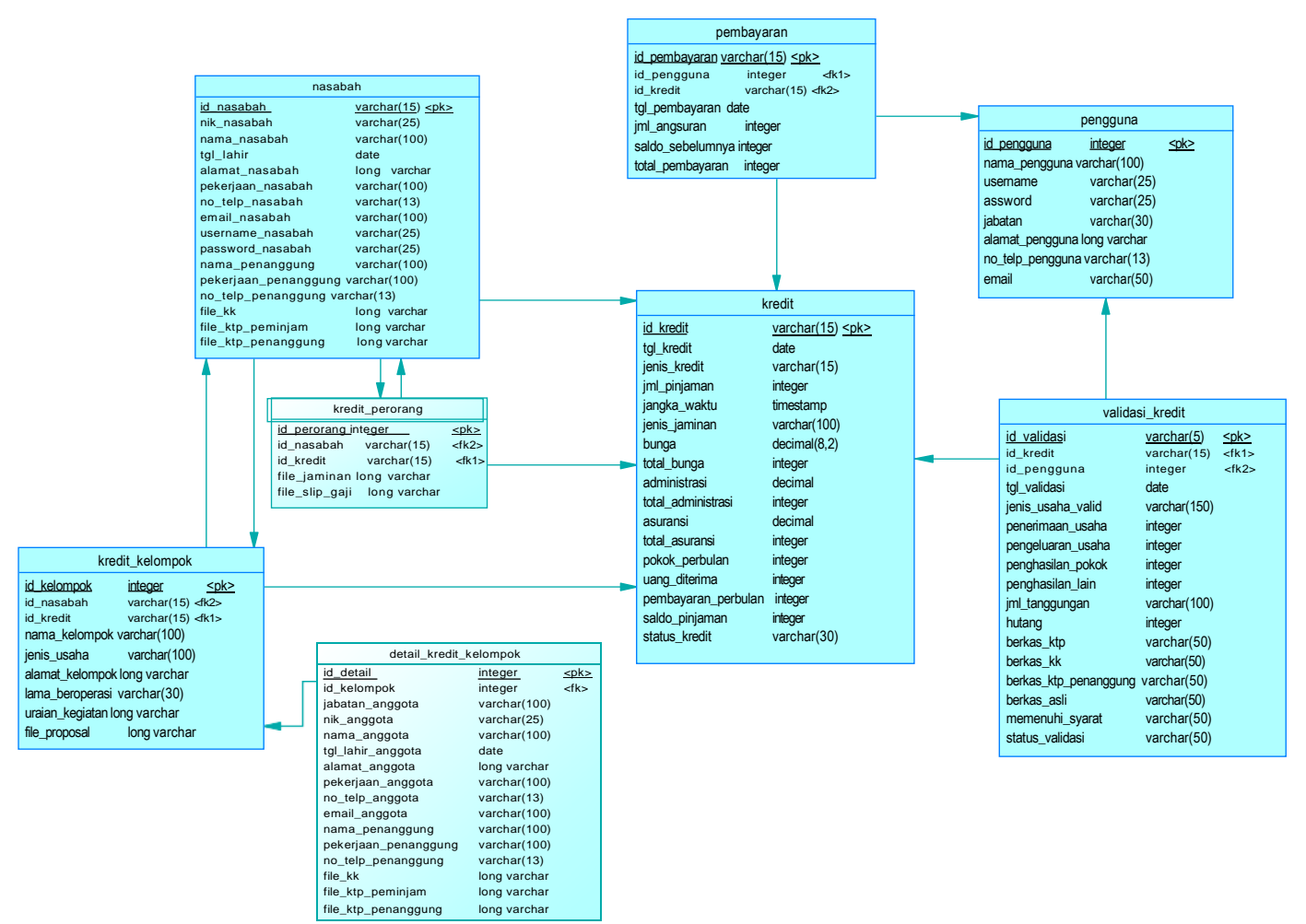

Gambar 1. Physical Data Model.

\section{HASIL DAN PEMBAHASAN}

Dalam sistem informasi pengajuan kredit BUM Desa Bersama Santhi Sedana implementasinya meliputi mengelola data pengguna, mengelola data nasabah, mengelola data kredit, mengelola pembayaran kerdit, dan mengelola laporan yang terdiri dari laporan pembayarn kredit, laporan tunggakan kredit, dan laporan perkembangan kredit.

Halaman Registrasi Nasabah

Halaman registrasi nasabah disediakan untuk nasabah yang belum terdaftar di sistem dan akan melakukan pengajuan kredit. Berikut tampilan halaman registrasi nasabah. 


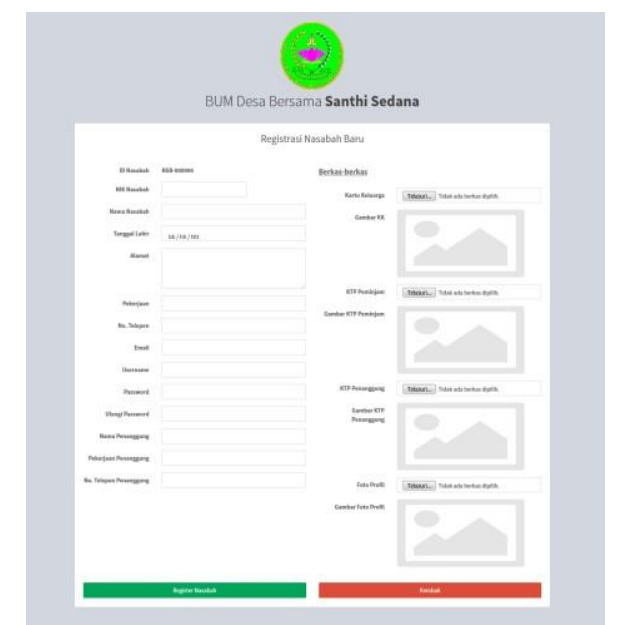

Gambar 2. Halaman Registrasi Nasabah.

Halaman Login

Halaman ini merupakan tapilan login. Pada halaman ini nasabah dan pengguna mengisi username dan password untuk masuk ke sistem. Seperti yang terlihat pada gambar berikut.

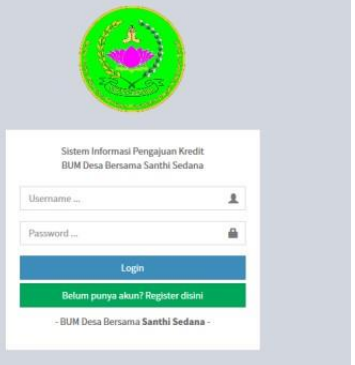

\section{Gambar 3. Halaman Login Nasabah}

Halaman Data Pengguna

Data pengguna disini merupakan data anggota BUM Desa Bersama Santhi Sedana yang berperan dalam mengelola data ini dalah sekretaris BUM Desa.

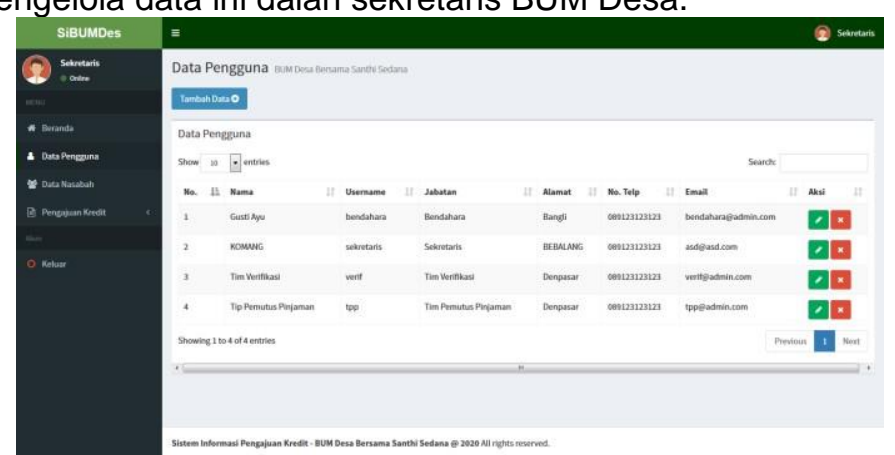

Gambar 4. Halaman Data Pengguna

Halaman Data Nasabah

Halaman menu data nasabah menampilkan daftar nama nasabah yang terdaftar dalam sistem. Pada bagian tabel terdapat aksi detail,ubah, dan hapus data. Pencarian data nasabah dapat cari melalui kotak search di bagian kanan atas tabel data nasabah, seperti pada gambar berikut. 


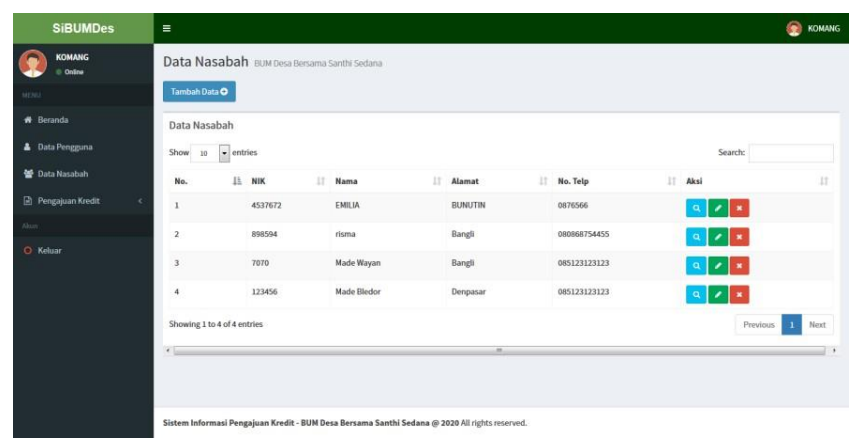

\section{Gambar 5. Halaman Data Nasabah}

Halaman Pengajuan Kredit Kelompok

Halaman ini menampilkan form yang harus dilengkapi nasabah apabila akan mengajukan kredit kelompok. Berikut tampilan halaman tambah data pengajuan kredit kelompok Gambar 8.

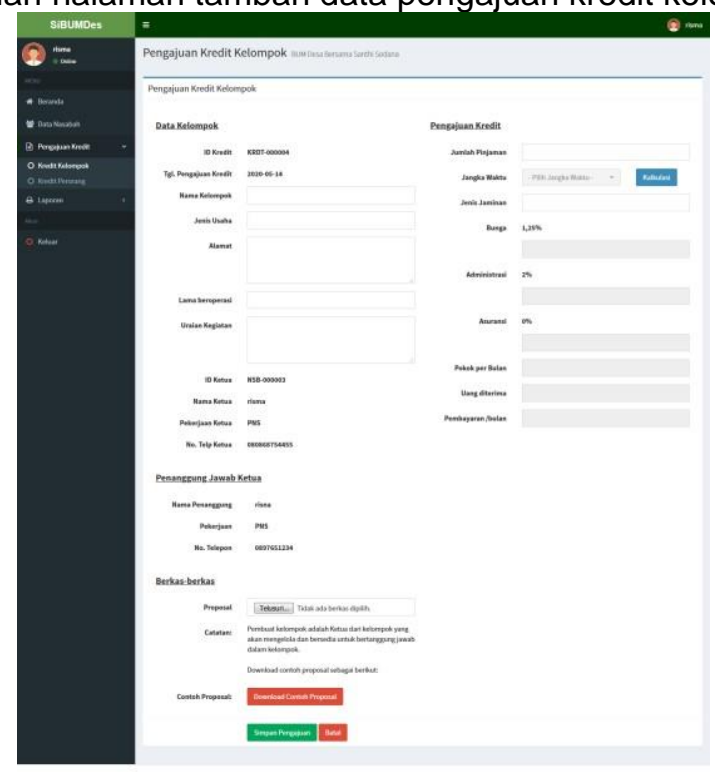

Gambar 6. Halaman Pengajuan Kredit Kelompok.

Halaman Pengajuan Kredit Perorangan

Pada halaman ini nasabah ditampilkan form yang harus dilengkapi untuk mengajukan kredit, seperti pada Gambar 9.

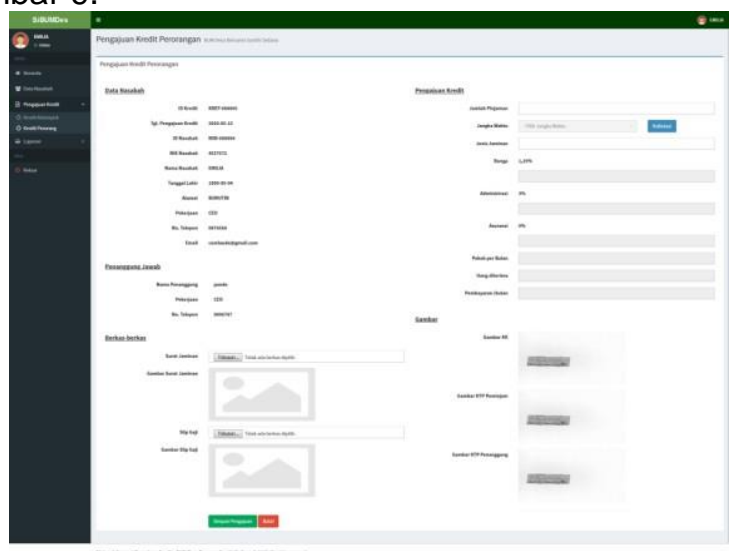

Gambar 7. Halaman Pengajuan Kredit Perorangan 
Halaman Verifikasi Kredit Kelompok

Halaman ini menampilkan identitas kelompok, rincian dana yang diajukan, daftar anggota kelompok, dan proposal kelompok. Berikut ini tampilan halaman tambah verifikasi pengajuan kredit.

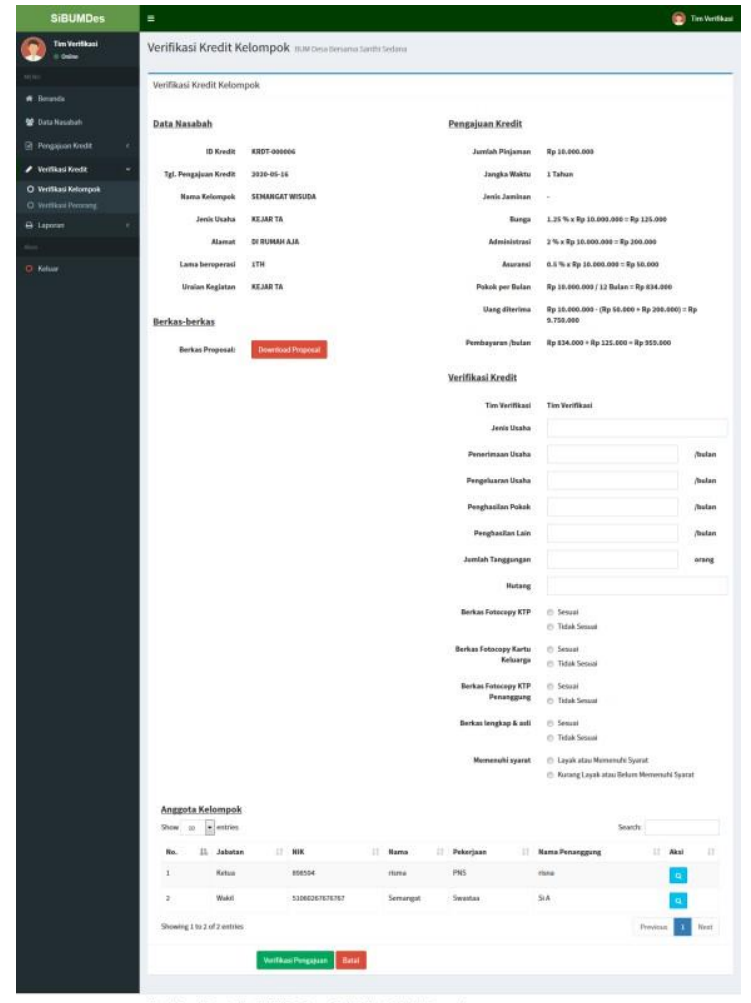

\section{Gambar 8. Halaman Verifikasi Pengajuan Kredit Kelompok.}

Halaman Verifikasi Pengajuan Kredit Perorangan

Pada halaman ini ditampilkan identitas nasabah, rincian pengajuan kredit, dan berkas kelengkapan pengajuan kredit. Berikut ini tampilan halaman tambah data verifikasi kredit perorangan.

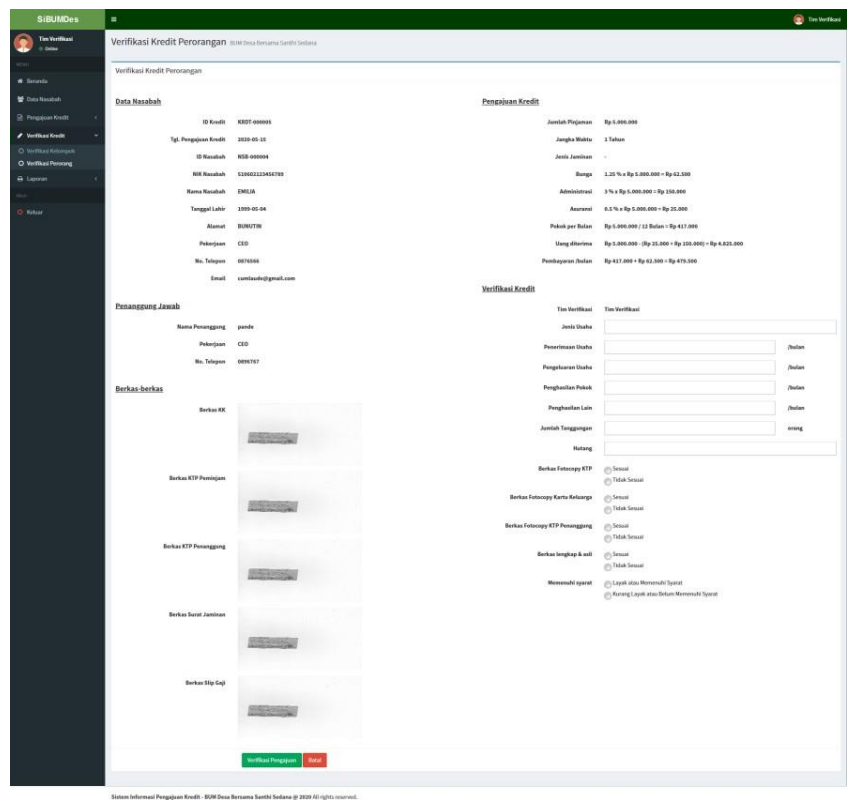

Gambar 9. Halaman Verifikasi Pengajuan Kredit Perorangan. 
Tampilan Halaman Menu Validasi Kredit Kelompok

Halaman ini merupakan akses yang diberikan kepada TPP (Tim Pemutus Pinjaman) untuk menambah validasi kredit kelompok apabila sudah dianggap layak untuk didanai. Pada halaman ini ditampilkan daftar nasabah yang pengajuannya telah divalidasi, aksi detail untuk melihat rincian validasi kredit, dan button tambah validasi untuk memvalidasi hasil verifikasi kredit. Berikut ini tampilan halaman validasi kredit.

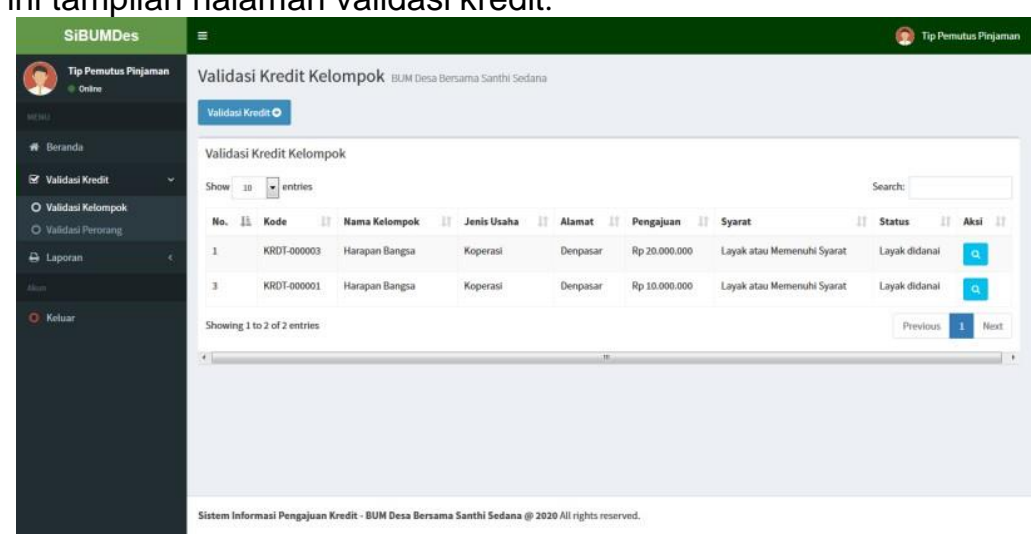

\section{Gambar 10.Halaman Validasi Kredit Nasabah}

Halaman Pembayaran Kredit Nasabah

Halaman ini menampilkan rincian kredit nasabah, bendahara akan mengisi jumlah angsuran yang dibayarkan nasabah. Berikut ini tampilan halaman tambah pembayaran kredit.

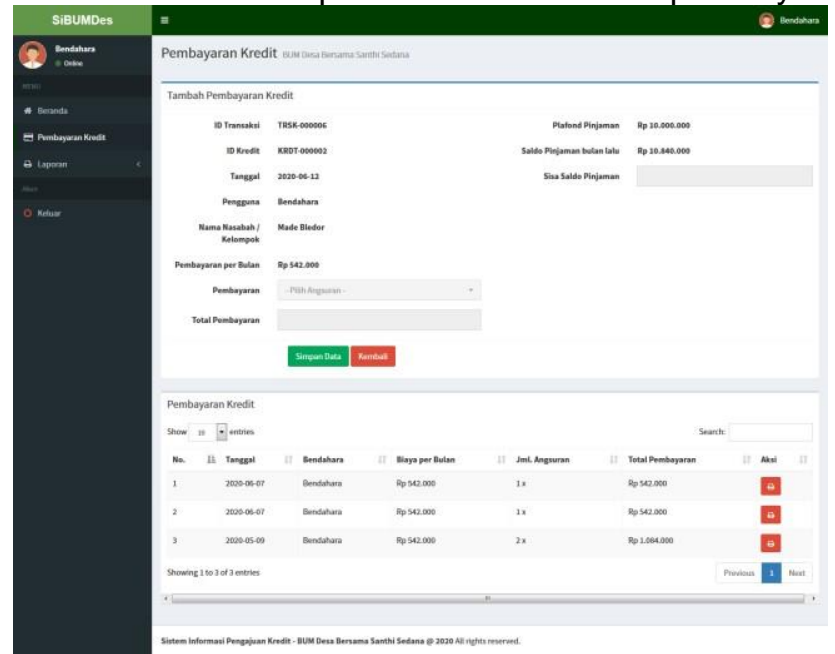

Gambar 11. Halaman Pembayaran Kredit Nasabah.

Halaman Laporan Pembayaran Kredit

Halaman ini menampilkan pembayaran kredit yang telah dibayarkan nasabah sesuai dengan periode waktu pembayaran, yang memiliki hak akses untuk halaman ini adalah Tim Verifikasi, Tim Pemutus Pinjaman, dan bendahara. Berikut ini tampilan halaman laporan pembayaran kredit. 


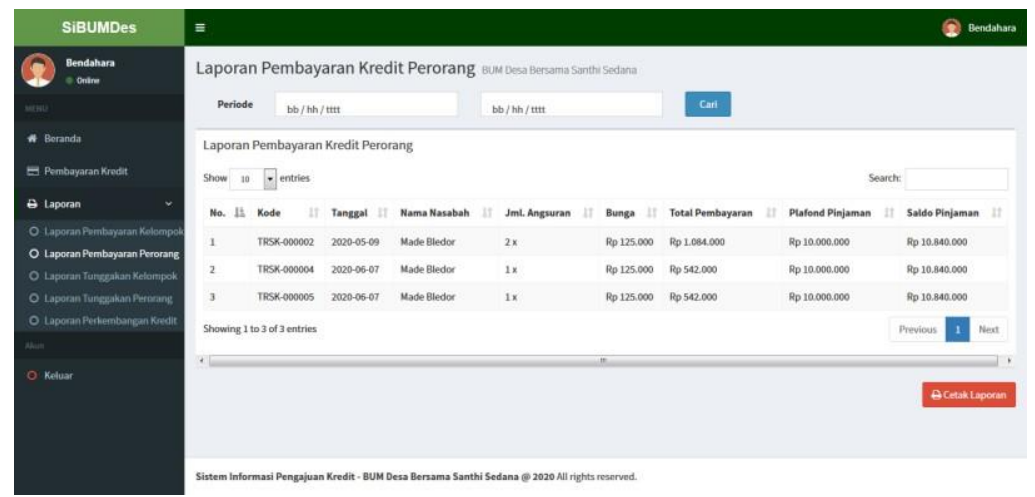

Gambar 12. Halaman Laporan Pembayaran Kredit.

Halaman Laporan Tunggakan Kredit

Halaman ini menampilkan daftar nasabah yang belum melakukan pembayaran kredit berdasarkan periode bulan dan tahun pembayaran, yang memiliki hak akses untuk halaman ini adalah Tim Verifikasi, Tim Pemutus Pinjaman, dan bendahara, namun hanya bendahara yang dapat mencetak laporan. Berikut ini tampilan halaman laporan tunggakan kredit nasabah.

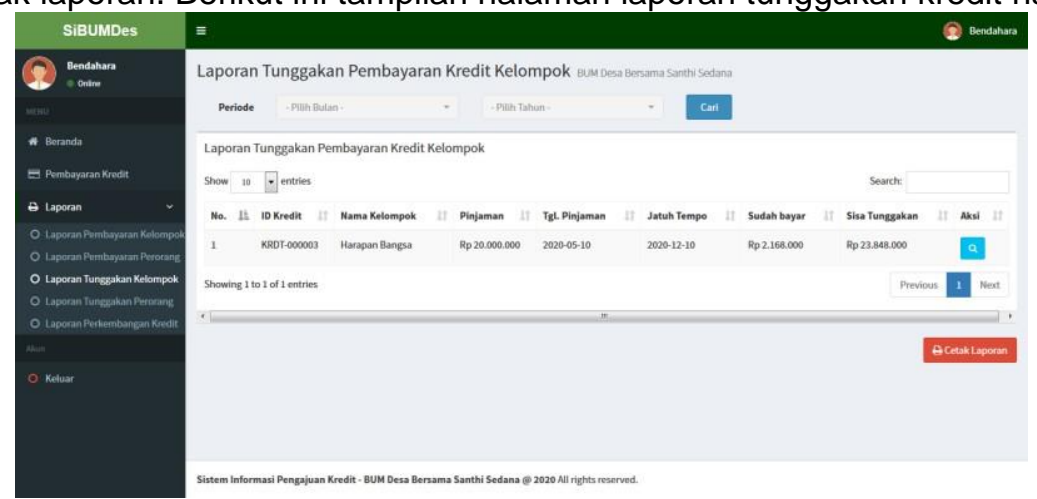

Gambar 13. Halaman Laporan Tunggakan Kredit

Halaman Laporan Perkembangan Kredit

Halaman ini menampilkan perkembangan kredit BUM Desa per tahunnya yang disajikan dalam tabel terdiri dari kolom bulan, jumlah pembiayaan, bunga yang diterima, dan jumlah pengembalian atas angsuran kredit. Yang memiliki hak akses untuk halaman ini adalah Tim Verifikasi, Tim Pemutus Pinjaman, dan bendahara, namun hanya bendahara yang dapat mencetak laporan Berikut ini tampilan halaman laporan perkembangan kredit BUM Desa.

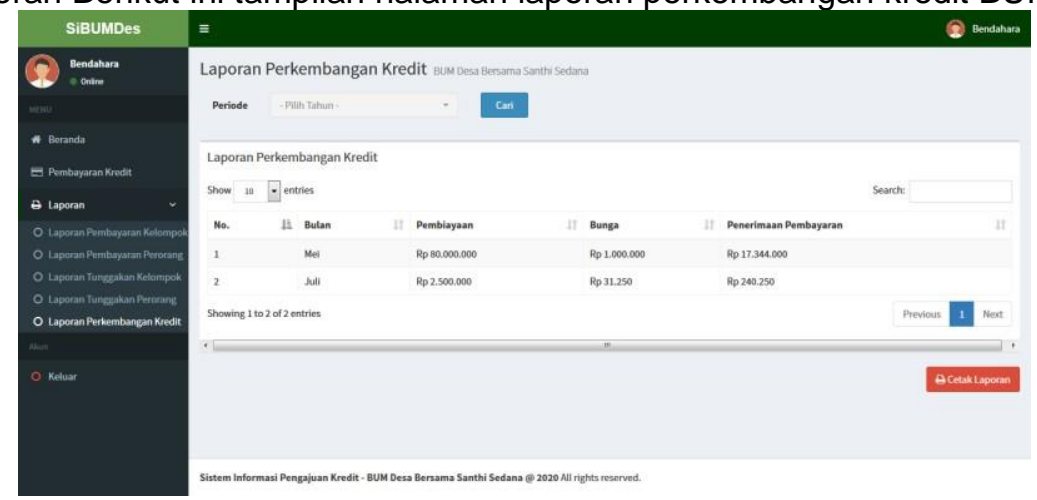

Gambar 14. Halaman Laporan Perkembangan Kredit 


\section{Skenario Pengujian}

Skenario pengujian sistem dilakukan untuk mengambil apakah sistem yang dirancang dapat berfungsi dengan baik. Pengujian sistem merupakan suatu kegiatan atau proses yang dilakukan untuk memastikan apakah fungsi dan atribut pada sistem telah bekerja dengan baik dan berfungsi sesusai dengan harapan (Tri et al., 2019). Dalam pengujian sistem informasi pengajuan kredit ini digunakan metode black box testing yaitu pengujian yang terfokus pada fungsi yang terdapat di dalam sistem. Testing atau pengujian dilakukan menggunakan Metode Black Box yang juga sering disebut juga Glass-Box testing, merupakan pengujian yang menggunakan kontrol struktur dari rancangan prosedural untuk melakukan test case dan mengetahui internal dari website(Wibawa, Ambarwati, \& Azam, 2017).

Tabel 1 Skenario Pengujian

\begin{tabular}{|c|c|c|c|c|}
\hline No & Uji & Skenario Uji & $\begin{array}{c}\text { Hasil yang } \\
\text { diharapkan }\end{array}$ & Hasil Pengujian \\
\hline 1 & $\begin{array}{l}\text { Halaman } \\
\text { Registrasi }\end{array}$ & $\begin{array}{l}\text { Mengisi semua } \text { field } \\
\text { registrasi } \\
\text { mengunggah semua } \\
\text { berkas, lalu mengklik } \\
\text { button "registrasi } \\
\text { nasabah" }\end{array}$ & $\begin{array}{lr}\text { Sistem mampu } \\
\text { menyimpan data } \\
\text { registrasi } \\
\text { pengguna. }\end{array}$ & $\begin{array}{l}\text { Sistem menampilkan alert } \\
\text { "Sukses!. } \quad \text { Registrasi } \\
\text { nasabah berhasil silakan } \\
\text { login untuk melanjutkan" }\end{array}$ \\
\hline 2 & $\begin{array}{l}\text { Halaman } \\
\text { Login }\end{array}$ & $\begin{array}{l}\text { Mengisi username dan } \\
\text { password dengan } \\
\text { benar, mengklik button } \\
\text { login. }\end{array}$ & $\begin{array}{l}\text { Sistem mampu } \\
\text { menyimpan data } \\
\text { login pengguna. }\end{array}$ & $\begin{array}{l}\text { Sistem menampilkan alert } \\
\text { "Sukses!". } \\
\text { diarahkan kengguna } \\
\text { dashboard sistem }\end{array}$ \\
\hline 3 & $\begin{array}{l}\text { Data } \\
\text { Pengguna }\end{array}$ & $\begin{array}{lr}\text { Mengisi } & \text { semua field } \\
\text { data } & \text { pengguna, } \\
\text { mengklik } & \text { button } \\
\text { simpan data. } & \end{array}$ & $\begin{array}{l}\text { Mampu menyimpan } \\
\text { semua data yang } \\
\text { di-input pengguna. }\end{array}$ & $\begin{array}{l}\text { Sistem menampilkan alert } \\
\text { sukses "Data berhasil } \\
\text { disimpan". }\end{array}$ \\
\hline 4 & $\begin{array}{l}\text { Data } \\
\text { Nasabah }\end{array}$ & $\begin{array}{l}\text { Mengisi semua field } \\
\text { identitas nasabah dan } \\
\text { mengunggah semua } \\
\text { berkas, lalu mengklik } \\
\text { button "Simpan Data" }\end{array}$ & $\begin{array}{l}\text { Mampu menyimpan } \\
\text { semua data yang } \\
\text { di-input pengguna. }\end{array}$ & $\begin{array}{l}\text { Sistem menampilkan alert } \\
\text { "Sukses!. Data berhasil } \\
\text { disimpan" }\end{array}$ \\
\hline 5 & $\begin{array}{l}\text { Data } \\
\text { Pengajua } \\
\text { n Kredit }\end{array}$ & $\begin{array}{l}\text { Mengisi semua field } \\
\text { data dan rincian kredit, } \\
\text { mengunggah berkas } \\
\text { pengajuan kredit. Pilih } \\
\text { Simpan Pengajuan. }\end{array}$ & $\begin{array}{l}\text { Mampu menyimpan } \\
\text { semua data yang } \\
\text { di-input pengguna. }\end{array}$ & $\begin{array}{l}\text { Sistem menampilkan alert } \\
\text { sukses "Data Berhasil } \\
\text { Disimpan" }\end{array}$ \\
\hline 6 & $\begin{array}{l}\text { Data } \\
\text { Verifikasi }\end{array}$ & $\begin{array}{l}\text { Mengisi field verifikasi } \\
\text { kredit dan memilih } \\
\text { check list keabsahan } \\
\text { dokumen, lalu } \\
\text { mengklik button } \\
\text { verifikasi pengajuan. }\end{array}$ & $\begin{array}{l}\text { Mampu menyimpan } \\
\text { semua data yang } \\
\text { di-input pengguna. }\end{array}$ & $\begin{array}{l}\text { Sistem menampilkan alert } \\
\text { sukses "Data Berhasil } \\
\text { Disimpan" }\end{array}$ \\
\hline 7 & $\begin{array}{l}\text { Validasi } \\
\text { Pengajua } \\
\text { n Kredit }\end{array}$ & $\begin{array}{l}\text { Memilih checklist } \\
\text { kelayakan dokumen, } \\
\text { lalu mengklik button } \\
\text { validasi pengajuan. }\end{array}$ & $\begin{array}{l}\text { Sistem mampu } \\
\text { menyimpan semua } \\
\text { data yang di-input } \\
\text { pengguna. }\end{array}$ & $\begin{array}{l}\text { Sistem menampilkan alert } \\
\text { sukses "Data Berhasil } \\
\text { Disimpan" }\end{array}$ \\
\hline 8 & $\begin{array}{l}\text { Data } \\
\text { Transaksi } \\
\text { Pembayar } \\
\text { an Kredit }\end{array}$ & $\begin{array}{l}\text { Memilih pembayar } \\
\text { yang akan dilakukan, } \\
\text { lalu mengklik button } \\
\text { simpan data. }\end{array}$ & $\begin{array}{l}\text { Sistem mampu } \\
\text { menyimpan semua } \\
\text { data yang di-input } \\
\text { pengguna, dan } \\
\text { menampilkan bukti } \\
\text { pembayaran kredit. }\end{array}$ & \begin{tabular}{lr}
\multicolumn{2}{l}{ Sistem menampilkan alert } \\
sukses "Data & Berhasil \\
Disimpan" & dan \\
menampilkan & cetak \\
pembayaran. &
\end{tabular} \\
\hline
\end{tabular}




\begin{tabular}{|l|c|l|l|l|}
\hline No & Uji & \multicolumn{1}{|c|}{ Skenario Uji } & \multicolumn{1}{|c|}{$\begin{array}{c}\text { Hasil yang } \\
\text { diharapkan }\end{array}$} & \multicolumn{1}{c|}{ Hasil Pengujian } \\
\hline 9 & Laporan & $\begin{array}{l}\text { Memilih periode bulan } \\
\text { dan tahun yang akan } \\
\text { ditampilkan, mengklik } \\
\text { button cari. }\end{array}$ & $\begin{array}{l}\text { Sistem mampu } \\
\text { menampilkan } \\
\text { laporan sesuai } \\
\text { periode yang dicari. }\end{array}$ & $\begin{array}{l}\text { Sistem laporan sesuai periode } \\
\text { yang dicari. }\end{array}$ \\
\hline
\end{tabular}

\section{KESIMPULAN}

Kesimpulan yang dapat penulis ambil dalam pembangunan sistem informasi pengajuan kredit berbasis website pada BUM Desa Bersama Santhi Sedana antara lain;

1. Pembangunan sistem informasi pengajuan kredit ini dibangun dengan beberapa tahap yakni dimulai dari pengumpulan data, identifikasi masalah, analisa kebutuhan, membuat rancangan sistem melalui Data Flow Diagram, menentukan struktur basis data dengan Conceptual Data Model (CDM) dan Physical Data Model(PDM), serta membangun sistem dengan bahasa pemrograman PHP dan MySQL sebagai media penyimpanan datanya.

2. Sistem Informasi Pengajuan Kredit pada BUMDesa Bersama Santhi Sedana berbasis website yang dibangun ini dapat membantu pegawai dalam mengelola kredit dan mempermudah nasabah dalam mengajukan kredit.

3. Pembangunan sistem ini diuji menggunakan metode black box testing, yaitu pengujian yang dilakukan secara fungsional. Dari hasil pengujian, sistem pengajuan kredit yang dibangun sudah berfungsi sesuai dengan rancangan yang dibuat.

\section{DAFTAR PUSTAKA}

Hidayatullah, P., \& Kawistara. (2017). Pemrograman WEB. Bandung: Informatika Bandung. Ira Zulfa, Putra, I. N. T. A. (2018). Sistem Pengambilan Keputusan Untuk Penerimaan Pegawai Baru PT.PLN (Persero) Wilayah Aceh Dengan Metode Heuristik. Jurnal Ilmu Komputer, 11(2), 109. https://doi.org/10.24843/jik.2018.v11.i02.p06

Kasmir. (2016). Analisis Laporan Keuangan. Jakarta: PT.Rajagrafindo Persada.

Ni Luh Putu Putri Vera Handayani, I. N. T. A. P. (2019). Rancang Bangun Sistem Informasi Pengelolaan Surat Masuk dan Surat Keluar Berbasis Website pada Setum Polda Bali. International Journal of Natural Science and Engineering, 3(2), 43-48. https://doi.org/http://dx.doi.org/10.23887/ijnse.v3i2.22190

Putra, I. N. T. A., Bisenna, I. K. A., \& Kartini, K. S. (2018). Pengembangan Sistem Inventaris Berbasis QR Code Menggunakan Web Service pada Bidang Sarana dan Prasarana STMIK STIKOM Indonesia. Jurnal Nasional Pendidikan Teknik Informatika, 7.

Putra, I. N. T. A., Kartini, K. S., \& Dewi, L. G. K. (2019). Sentuhan Digital Bisnis (Teknologi Informasi) pada UMKM Studi Kasus: Pemasaran Produk Adi Upakara. International Journal of Natural Science and Engineering, 3(2), 79-84. https://doi.org/http://dx.doi.org/10.23887/ijnse.v3i2.22225

Sugiyono. (2015). Metode Penelitian Kombinasi. Bandung: Alfabeta.

Sukamto, R. A., \& Shalahudin, M. (2014). Rekayasa Perangkat Lunak Terstruktur dan Berorientasi Objek. (InformatikaBandung, Ed.). Bandung.

Tri, I. N., Putra, A., \& Kartini, K. S. (2019). Rancang Bangun Sistem Informasi Eksekutif pada STMIK STIKOM Indonesia. International Journal of Natural Science and Engineering, 3(3), 122-129. https://doi.org/http://dx.doi.org/10.23887/ijnse.v3i3.24147

Umar, H. (2013). Metode Penelitian untuk Skripsi dan Tesis. Jakarta: Rajawali.

Wibawa, A. B. P., Ambarwati, A., \& Azam, M. N. Al. (2017). Rancang Bangun Sistem Informasi Pengendalian Dokumen Pengajuan KPR pada PT. KKK Surabaya. Seminar Nasional Sistem Informasi, 1. 